\title{
PERAN BRAND IMAGE DALAM MEMEDIASI PENGARUH GREEN MARKETING TERHADAP KEPUTUSAN PEMBELIAN (Studi pada produk fashion merek Uniqlo di Denpasar)
}

\author{
M. Ega Nandaika ${ }^{1}$ \\ Ni Nyoman Rsi Respati \\ Fakultas Ekonomi dan Bisinis Universitas Udayana (Unud), Bali, Indonesia \\ email: nandaikaega@gmail.com
}

\begin{abstract}
ABSTRAK
Keputusan pembelian adalah kegiatan yang secara langsung dalam menentukan produk yang akan dibeli berdasarkan value atau nilai dari beberapa produk. Green marketing merupakan salah satu cara menambah value produk sekaligus menjaga kelestarian lingkungan. Tujuan penelitian ini adalah untuk mengetahui bagaimana peran brand image dalam memediasi pengaruh green marketing terhadap keputusan pembelian (Studi pada produk fashion merek Uniqlo di Denpasar). Penelitian ini dilakukan pada perusahaan Uniqlo. Sampel yang digunakan dalam penelitan ini berjumlah 100 responden dengan menggunakan metode purposive sampling. Teknik analisis data yang digunakan adalah path analysis. Hasil penelitian ini menunjukkan bahwa variabel green marketing berpengaruh positif dan signifikan terhadap brand image dan keputusan pembelian pada produk fashion merek Uniqlo di Denpasar, brand image berpengaruh positif dan signifikan terhadap keputusan pembelian pada produk fashion merek Uniqlo di Denpasar, Green marketing dapat memengaruhi keputusan pembelian pada produk fashion merek Uniqlo di Denpasar secara parsial melalui mediasi brand image. Dari segi brand image produk fashion merek Uniqlo harus tetap menjaga konsistensi dan meningkatkan program sustainability.
\end{abstract}

Kata Kunci: Green marketing, brand image, keputusan pembelian.

\begin{abstract}
Purchasing decision is an activity that directly determines the product to be purchased based on the value or value of some products. Green marketing is one way to increase product value while maintaining environmental sustainability. The purpose of this research is to find out how the role of brand image in mediating the influence of green marketing on purchasing decisions (Study on Uniqlo brand fashion products in Denpasar). This research was conducted at Uniqlo company. The sample used in this study amounted to 100 respondents using purposive sampling method. Analysis techniques used are path analysis. The results of this study showed that green marketing variables have a positive and significant effect on brand image and purchasing decisions on Uniqlo brand fashion products in Denpasar, brand image has a positive and significant effect on purchasing decisions on Uniqlo brand fashion products in Denpasar, Green marketing can influence purchasing decisions on Uniqlo brand fashion products in Denpasar partially through brand image mediation. In terms of brand image, Uniqlo fashion products must maintain consistency and improve sustainability program.
\end{abstract}

Keywords: Green marketing, brand image, purchasing decisions. 


\section{PENDAHULUAN}

Lingkungan merupakan suatu keadaan disekitar yang dapat mempengaruhi perkembangan dan tingkah laku mahluk hidup. Semakin hari kondisi lingkungan dan cuaca selalu berubah-ubah, hal tersebut diakibatkan karena adanya pemanasan global atau yang lebih dikenal dengan istilah global warming (Putra \& Suryani, 2015). Salah satu penyebab pemanasan global adalah pemakaian produk yang berbahaya secara terus-menerus dan limbah dari industri yang menyebabkan pencemaran pada lingkungan. Dari catatan terbaru yang dihimpun (radarbali.jawapos.com, 2020) dalam penelitian yang dilakukan, setiap hari Bali menghasilkan 4.281 ton atau 1,5 juta ton sampah per tahun. Jumlah sampah yang ada dikota Denpasar di hari normal bisa mencapai 600-800 ton per hari (radarbali.jawapos.com, 2019). Dengan maraknya sampah plastik sekali pakai, Gubernur Bali mengeluarkan kebijakan berupa Peraturan Gubernur Bali (Pergub) No.97 Tahun 2018 tentang Pembatasan Timbulan Sampah Plastik Sekali Pakai, (balipost.com, 2018). Dalam menjaga kelestarian lingkungan, masyarakat harus mengetahui produk yang digunakan aman bagi lingkungan, sehingga masyarakat mampu menentukan keputusan pembelian pada suatu produk.

Dalam menjaga kelestarian lingkungan, masyarakat harus mengetahui produk yang digunakan aman bagi lingkungan, sehingga masyarakat mampu menentukan keputusan pembelian pada suatu produk. Keputusan pemebelian adalah tahap dalam proses pengambilan keputusan pembeli dimana konsumen membeli suatu barang atau jasa Fure et al. (2015). Keputusan pembelian adalah suatu keputusan karena ketertarikan yang dirasakan oleh seseorang terhadap suatu produk, dan ingin membeli, mencoba, menggunakan, atau memiliki produk tersebut menurut Marlius (2017). Keputusan pembelian merupakan tahap dalam proses pengambilan keputusan dimana konsumen benar-benar membeli suatu produk yang dihasilkan perusahaan.

Pengambilan keputusan secara umum merupakan proses dalam memilih produk dari berbagai pilihan yang tersedia Jannah \& Ady (2017). Pengambilan keputusan merupakan suatu kegiatan individu yang secara langsung terlibat dalam menentukan untuk memilih barang yang akan dibeli dan dipergunakan. Sehubungan dengan hal tersebut, perusahaan perlu mengetahui mengapa dan bagaimana konsumen mengambil keputusan pembelian terhadap suatu produk, sehingga perusahaan mampu merancang strategi pemasaran yang sesuai dengan keinginan konsumen agar volume penjualan mengalami peningkatan.

Salah satu strategi pemasaran yang mementingkan kondisi dan pelestarian lingkungan adalah green marketing. Green marketing merupakan proses perencanaan bauran pemasaran yang memanfaatkan berubahnya kesadaran konsumen terhadap produk atau jasa yang lebih ramah lingkungan dengan merubah produk, cara pembuatan, dan pembungkusan yang lebih ramah lingkungan demi memuaskan dan memenuhi kebutuhan konsumen serta mengurangi dampak negatif kepada lingkungan dan juga mengajak konsumen untuk lebih peduli lingkungan (Stevanie, 2015).

Strategi pemasaran suatu produk bertujuan untuk meningkatkan brand image (Citra merek) perusahaan. Menurut (Prasetya et al., 2018) Brand Image (Citra merek) merupakan hal yang penting untuk menjadi prioritas utama bagi setiap perusahaan. 
Brand image menjadi suatu hasil pandang atau persepsi konsumen terhadap suatu merek tertentu, yang didasarkan atas pertimbangan dan perbandingan dengan beberapa merek lainnya, pada jenis produk yang sama (Wulandari \& Iskandar, 2018). Konsumen akan menjadikan brand image (Citra merek) sebagai acuan sebelum melakukan keputusan pembelian pada suatu produk.

Brand image menjadi suatu hasil pandang atau persepsi konsumen terhadap suatu merek tertentu, yang didasarkan atas pertimbangan dan perbandingan dengan beberapa merek lainnya, pada jenis produk yang sama Wulandari \& Iskandar (2018). Konsumen akan menjadikan brand image (Citra merek) sebagai acuan sebelum melakukan keputusan pembelian pada suatu produk. Brand image (Citra merek) digunakan untuk menciptakan kesadaran pada pelanggan potensial dan untuk menarik pelanggan yang belum pernah menggunakan sama sekali Cham et al. (2016). Brand Image yang positif adalah akan memberikan dampak nilai lebih terhadap konsumen, jika suatu merek memiliki citra yang buruk maka secara tidak langsung akan berdampak kepada konsumen dan kemungkinan besar konsumen tidak tertarik untuk melakukan pembelian.

Salah satu perusahaan global yang mengedepankan kondisi dan kelestarian lingkungan adalah Uniqlo. Uniqlo memiliki misi untuk membuat pakaian yang tidak cepat dibuang dan bertahan lama. Uniqlo juga memiliki program yang bernama sustainability Uniqlo. Program sustainability Uniqlo adalah membuat pakaian dengan bahan-bahan ramah lingkungan yang diharapkan bisa digunakan secara berkelanjutan. Selain menjaga kelestarian lingkungan program sustainability Uniqlo ini juga membantu masyarakat yang kurang mampu atau yang terdampak korban bencana diseluruh dunia, pada tahun 2019, Uniqlo telah mendonasikan 36,57 juta item secara global di 72 negara kepada pengungsi, korban bencana, dan orang yang membutuhkan. Selain itu Uniqlo memiliki misi mengurangi penggunaan pembungkus dengan plastik hingga $85 \%$ mulai dari tahun 2020

Dengan konsep green marketing pelaku usaha akan memperoleh manfaat yang lebih, yaitu mewujudkan produk-produk yang ramah lingkungan, mulai dari memenuhi tingginya permintaan produk ramah lingkungan dari konsumen yang akan berdampak kepada keputusan pembelian Widodo (2020). Pada penelitian yang dilakukan oleh Priyono (2017) bahwa green marketing dipandang mampu untuk meningkatkan pengambilan keputusan pembelian. Sedangkan penelitian yang dilakukan oleh Hello \& Momani (2014) bahwa konsep green marketing tidak berpengaruh signifikan terhadap keputusan pembelian di Arab, hal ini membuktikan bahwa konsumen di Arab tidak peduli dan tidak mau untuk membayar lebih terhadap produk ramah lingkungan. Sejalan dengan penelitian Ahmad et al. (2016) menyatakan bahwa green marketing tidak berpengaruh signifikan, dalam persepsi konsumen green marketing bukan faktor utama dalam melakukan keputusan pembelian pada produk The Body Shop.

Berdasarkan konteks green marketing yang telah diuraikan di atas, peneliti ingin menambahkan variabel mediasi yaitu brand image karena ada penelitian yang menyatakan bahwa green marketing tidak berpengaruh signifikan terhadap keputusan 
pembelian. Oleh karena itu, peneliti tertarik untuk melakukan penelitian dengan mengambil judul "Peran Brand Image Dalam Memediasi Green Marketing Terhadap Keputusan Pembelian (Studi pada produk fashion merek Uniqlo di Denpasar)".

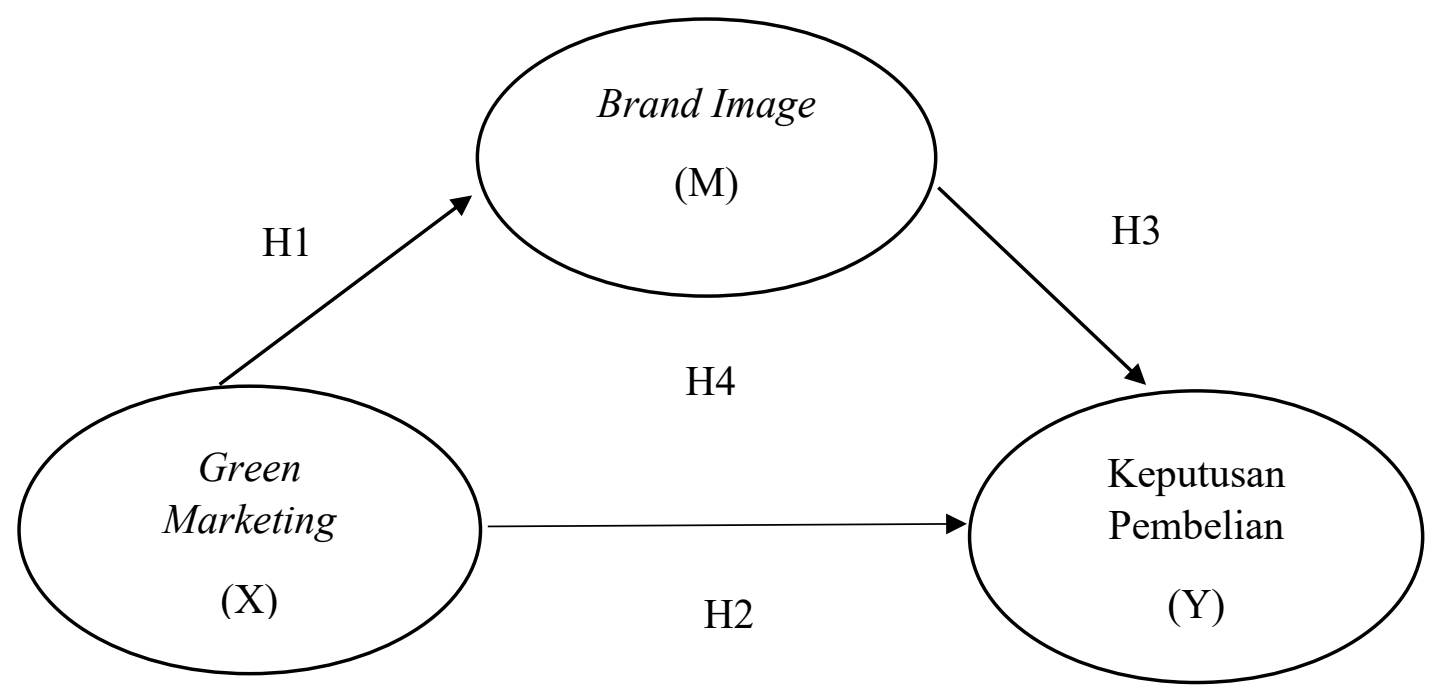

Gambar 1. Kerangka Konseptual

Pelaksanaan green marketing yang terdiri dari green product, green price, green promotion, green place mempunyai pengaruh yang signifikan terhadap proses brand image Setyaningrum \& Madiawati (2019). Hasil penelitian yang dilakukan oleh Sari \& Setiawan (2017) green marketing berpengaruh positif dan signifikan terhadap brand image. Berdasarkan hasil penelitian yang dilakukan oleh Agustina et al. (2016) penerapan strategi pemasaran hijau yang dilakukan oleh perusahaan ditengah isu permasalahan lingkungan yang semakin memburuk dapat membentuk citra merek yang baik di mata konsumen. Penelitian yang sama dilakukan oleh Chalimatuz et al. (2017) yang menyatakan bahwa green marketing dapat berperan dalam mendorong persepsi positif dari konsumen terhadap brand image yang mengacu pada lingkungan. Hal ini menunjukkan bahwa strategi green marketing berkaitan dengan adanya produk ramah lingkungan yang secara tidak langsung membangun citra di benak konsumen. Wang et al. (2016) dalam penelitiannya menemukan bahwa green marketing dapat mempengaruhi brand image baik secara langsung maupun tidak langsung, melalui green cognition.

$\mathrm{H}_{1} \quad$ : Green marketing berpengaruh positif dan signifikan terhadap brand image

Dewi \& Rahyuda (2018) menyatakan bahwa green marketing memiliki peran penting dalam meningkatkan keputusan pembelian konsumen terhadap produk ramah lingkungan sehingga mampu mengurangi dampak negatif dari produk-produk sintetis yang dapat merusak lingkungan. Keputusan pembelian pada konsumen dilakukan 
dengan mencari informasi yang valid tentang produk yang akan digunakan. Jamira \& Yandi (2019) menyatakan bahwa green marketing mempengaruhi keputusan pembelian dalam membeli atau memilih suatu produk. Pada penelitian yang dilakukan oleh Priyono (2017) bahwa green marketing dipandang mampu untuk meningkatkan pengambilan keputusan pembelian. Dengan konsep green marketing pelaku usaha akan memperoleh manfaat yang lebih, yaitu mewujudkan produk-produk yang ramah lingkungan, mulai dari memenuhi tingginya permintaan produk ramah lingkungan dari konsumen yang akan berdampak kepada keputusan pembelian Widodo (2020).

$\mathrm{H}_{2}$ : Green marketing berpengaruh positif dan signifikan terhadap keputusan pembelian.

Hasil penelitian dari (Cahyani \& Sutrasmawati, 2016) menyatakan bahwa semakin positif brand image pada perusahaan maka semakin meningkatnya penjualan, dan akan mempengaruhi keputusan pembelian konsumen. Hasil penelitian (Adiwidjaja \& Tarigan, 2017) brand image berpengaruh positif dan signifikan terhadap keputusan pembelian sepatu Converse baik melalui hubungan langsung maupun tidak langsung. Sejalan dengan penelitian (Dewi \& Aksari, 2017) brand image berpengaruh positif dan signifikan terhadap keputusan pembelian. Uji hipotesis yang dilakukan oleh Wulandari \& Iskandar (2018) menemukan bahwa citra merek memiliki pengaruh positif dan signifikan terhadap keputusan pembelian Viva Kosmetik. Semakin tinggi citra merek maka akan berpegaruh terhadap keputusan pembelian yang berlanjut.

$\mathrm{H}_{3} \quad$ : Brand image berpengaruh positif terhadap keputusan pembelian

Konsumen semakin cerdas dalam menyikapi isu pemanasan global yang semakin gencar. Green marketing merupakan salah satu solusi dan terobosan yang efektif dalam mengurangi pemanasan global. Perusahaan yang mampu membangun green marketing yang kuat, maka dengan mudah akan membangun citra positif pada perusahaan di benak konsumen. Brand image merupakan suatu pandangan konsumen terhadap produk atau jasa berdasarkan pengalaman, pengetahuan dan terhadap merek tersebut. Keputusan pembelian terjadi karena citra produk, citra perusahaan, dan citra pemakai yang baik. Brand image yang kuat memungkinkan konsumen untuk mengidentifikasi kebutuhan yang memuaskan dan cenderung memilih produk tersebut untuk melakukan suatu keputusan pembelian.Hasil penelitian (Adiwidjaja \& Tarigan, 2017) brand image berpengaruh positif dan signifikan terhadap keputusan pembelian.Penelitian yang dilakukan oleh (Chalimatuz et al., 2017) yang menyatakan bahwa green marketing dapat berperan dalam mendorong persepsi positif dari konsumen terhadap brand image yang mengacu pada lingkungan. Penelitian yang dilakukan oleh (Cahyani \& Sutrasmawati, 2016) memperoleh hasil bahwa brand image mempunyai pengaruh yang signifikan terhadap keputusan pembelian. Penelitian yang dilakukan oleh (Dewi \& Aksari, 2017) Brand image mampu memediasi pengaruh green marketing terhadap keputusan pembelian

H4 : Brand image mampu memediasi pengaruh green marketing terhadap keputusan pembelian 


\section{METODE PENELITIAN}

Penelitian ini termasuk jenis penelitian dengan menggunakan metode asosiatif, di mana untuk mengetahui sebab akibat dari variabel yang memengaruhi terhadap variabel yang dipengaruhi. Penelitian ini dilakukan di Kota Denpasar. Objek penelitian ini adalah perilaku konsumen khususnya mengenai keputusan pembelian produk dalam melakukan pembelian terhadap produk fashion merek Uniqlo yang ditentukan oleh brand image dan green marketing. Subjek penelitian ini adalah konsumen yang pernah membeli produk fashion merek Uniqlo.

Data kualitatif pada penelitian ini adalah pendapat responden terhadap pernyataan yang meliputi Green Marketing, Brand Image, dan Keputusan Pembelian. Data kuantitatif dalam penelitian ini berupa data penilaian (scoring) terhadap tanggapan responden dari hasil kuesioner yang telah disebar di Kota Denpasar. Data primer dalam penelitian ini adalah responden yang memberikan penilaian atas pernyataan yang terdapat dalam kuesioner mengenai variabel-variabel dalam penelitian. Data sekunder dalam penelitian ini adalah institusi atau pihak terkait yang mempublikasikan data yang dikutip terkait dengan topik penelitian.

Penelitian ini menggunakan kuesioner sebagai alat pengumpulan data, sehingga perlu dilakukan pengujian validitas dan realibilitas agar kuisioner tersebut layak untuk digunakan. Populasi dalam penelitian ini adalah masyarakat Kota Denpasar yang membeli produk fashion merek Uniqlo dari tahun 2018 yang jumlahnya tidak dapat disebutkan atau dihitung (infinite). Sampel dalam penelitian ini adalah konsumen yang pernah membeli produk fashion merek Uniqlo. Teknik penentuan sampel yang digunakan pada penelitian ini adalah non probability sampling, dengan metode purposive sampling, yaitu teknik penentuan sampel dengan pertimbangan atau kriteria tertentu. Ukuran sampel ditetapkan yaitu sebanyak 120 responden dengan metode pengumpulan data dengan menyebarkan kuesioner cara online melalui google form Variabel dalam kuesioner diukur dengan menggunakan Skala Likert.

Teknik analisis data yang digunakan dalam penelitian ini adalah Path analysis (analisis jalur). Pengujian regresi linier berganda dapat dilakukan setelah model dari penelitian ini memenuhi syarat, yaitu lolos uji asumsi klasik terlebih dahulu. Variabel mediasi merupakan variabel yang mempengaruhi antara variabel bebas dan variabel terikat. Uji sobel digunakan untuk menilai apakah variabel yang digunakan merupakan variabel mediasi

\section{HASIL DAN PEMBAHASAN}

Data responden yaitu profil dari 100 responden yang berpartisipasi dalam pengumpulan data melalui kuesioner penelitian yang menampilkan jenis kelamin, usia, pendidikan yang diselesaikan, dan pekerjaan. 
E-Jurnal Manajemen, Vol. 10, No. 6, 2021 : 539-559

Tabel 1.

Data Responden

\begin{tabular}{|c|c|c|c|c|}
\hline No & Variabel & Klasifikasi & Jumlah (orang) & $\begin{array}{c}\text { Persentase } \\
(\%)\end{array}$ \\
\hline \multirow{3}{*}{1} & \multirow{2}{*}{ Jenis Kelamin } & Laki - Laki & 60 & 60 \\
\hline & & Perempuan & 40 & 40 \\
\hline & \multirow{5}{*}{ Usia } & Jumlah & 100 & 100 \\
\hline \multirow{4}{*}{2} & & 17-21 Tahun & 37 & 37 \\
\hline & & 22-26 Tahun & 48 & 48 \\
\hline & & 27-32 Tahun & 10 & 10 \\
\hline & & 33-38 Tahun & 4 & 4 \\
\hline \multirow{4}{*}{3} & \multirow{4}{*}{$\begin{array}{l}\text { Pendidikan } \\
\text { terakhir }\end{array}$} & Jumlah & 100 & 100 \\
\hline & & SMA/SMK & 42 & 42 \\
\hline & & Diploma & 17 & 17 \\
\hline & & S1 & 29 & 29 \\
\hline \multirow{7}{*}{4} & \multirow{7}{*}{ Pekerjaan } & $\mathrm{S} 2$ & 12 & 12 \\
\hline & & Jumlah & 100 & 100 \\
\hline & & Pelajar/Mahasiswa & 63 & 63 \\
\hline & & Wirasawasta & 23 & 23 \\
\hline & & PNS & 2 & 2 \\
\hline & & Lainnya & 12 & 12 \\
\hline & & Jumlah & 100 & 100 \\
\hline
\end{tabular}

Sumber: data diolah, 2020

Berdasarkan Tabel 1. dapat di lihat jumlah pembeli produk Uniqlo di Kota Denpasar yang di jadikan sampel sebanyak 100 orang. Jika di lihat dari jenis kelamin, jenis kelamin laki-laki mendominasi dalam penelitian ini dengan presentase sebesar 60 persen. Jika di lihat dari usia, yang memiliki usia 22-26 tahun mendominasi dengan presentase sebesar 48 persen. Jika di lihat dari tingkat pendidikan yang memiliki tingkat pendiddikan terakhir SMA/SMK yang mendominasi dengan persentase sebesar 42 persen. Jika di lihat dari Pekerjaan yang memiliki pekerjaan sebagai pelajar/mahasiswa mendominasi dengan persentase sebesar 63 persen.

Tabel 2.

Hasil Uji Validitas

\begin{tabular}{|c|c|c|c|c|}
\hline No. & Variabel & Instrumen & $\begin{array}{c}\text { Pearson } \\
\text { Correlation }\end{array}$ & Keterangan \\
\hline \multirow{4}{*}{1.} & \multirow{4}{*}{ Green Marketing (X) } & $\mathrm{X} 1$ & 0,875 & Valid \\
\hline & & $\mathrm{X} 2$ & 0,763 & Valid \\
\hline & & $\mathrm{X} 3$ & 0,848 & Valid \\
\hline & & $\mathrm{X} 4$ & 0,849 & Valid \\
\hline & & M1 & 0,894 & Valid \\
\hline \multirow[t]{2}{*}{2.} & Brand Image (M) & M2 & 0,850 & Valid \\
\hline & & M3 & 0,832 & Valid \\
\hline 3. & Keputusan Pembelian (Y) & Y1 & 0,857 & Valid \\
\hline
\end{tabular}

Bersambung... 
Lanjutan Tabel 2.

\begin{tabular}{|c|c|c|c|c|}
\hline No. & Variabel & Instrumen & $\begin{array}{c}\text { Pearson } \\
\text { Correlation }\end{array}$ & Keterangan \\
\hline & & $\begin{array}{l}\mathrm{Y} 2 \\
\mathrm{Y} 3\end{array}$ & $\begin{array}{l}0,932 \\
0828\end{array}$ & Valid \\
\hline
\end{tabular}

Sumber: data diolah, 2020

Tabel 2. menunjukan bahwa seluruh instrumen variabel penelitian berupa Green Marketing, Brand Image dan Keputusan Pembelian telah memenuhi syarat uji validitas yang dimana nilai skor total Pearson Correlation masing-masing instrumen berada diatas 0,30 dan mimiliki nilai signifikansi yang lebih kecil dari $5 \%(0,05)$, maka instrumen layak digunakan menjadi alat ukur variabel-variabel tersebut.

Tabel 3.

Uji reliabilitas instrument

\begin{tabular}{llcc}
\hline No. & \multicolumn{1}{c}{ Variabel } & Cronbach's Alpha & Keterangan \\
\hline 1. & Green Marketing $(\mathrm{X})$ & 0,852 & Reliabel \\
2. & Brand Image $(\mathrm{M})$ & 0,820 & Reliabel \\
3. & Keputusan Pembelian $(\mathrm{Y})$ & 0,841 & Reliabel \\
\hline
\end{tabular}

Sumber: data diolah, 2020

Tabel 3 uji reliabilitas pada masing-masing variabel berada pada titik diatas 0,60 yang ditunjukkan pada hasil Cronbach's Alpha, maka dapat dikatakan seluruh instrumen telah memenuhi syarat reliabilitas.

Tabel 4.

Deskripsi Jawaban Responden Terhadap Green Marketing

\begin{tabular}{|c|c|c|c|c|c|c|c|c|c|}
\hline \multirow[t]{2}{*}{ No } & \multirow{2}{*}{ Pernyataan } & \multicolumn{5}{|c|}{$\begin{array}{c}\text { Proporsi Jawaban Responden } \\
\text { (orang) }\end{array}$} & \multirow{2}{*}{$\begin{array}{c}\text { Juml } \\
\text { ah }\end{array}$} & \multirow{2}{*}{$\begin{array}{l}\text { Rata- } \\
\text { rata }\end{array}$} & \multirow{2}{*}{ Kriteria } \\
\hline & & 1 & 2 & 3 & 4 & 5 & & & \\
\hline 1 & $\begin{array}{l}\text { Saya merasa Uniqlo } \\
\text { merupakan produk yang } \\
\text { menggunakan bahan } \\
\text { ramah lingkungan }\end{array}$ & - & - & 17 & 56 & 27 & 410 & 4.10 & Setuju \\
\hline 2 & $\begin{array}{l}\text { Saya melihat produk } \\
\text { Uniqlo dipromosikan } \\
\text { dengan memanfaatkan } \\
\text { teknologi digital } \\
\text { sehingga dapat } \\
\text { meminimalisir kerusakan } \\
\text { bagi lingkungan }\end{array}$ & - & - & 7 & 45 & 48 & 441 & 4.41 & $\begin{array}{l}\text { Sangat } \\
\text { Setuju }\end{array}$ \\
\hline
\end{tabular}


E-Jurnal Manajemen, Vol. 10, No. 6, 2021 : 539-559

Lanjutan Tabel 4.

\begin{tabular}{|c|c|c|c|c|c|c|c|c|c|}
\hline \multirow[t]{2}{*}{ No } & \multirow[t]{2}{*}{ Pernyataan } & \multicolumn{5}{|c|}{$\begin{array}{c}\text { Proporsi Jawaban Responden } \\
\text { (orang) }\end{array}$} & \multirow{2}{*}{$\begin{array}{c}\text { Juml } \\
\text { ah }\end{array}$} & \multirow{2}{*}{$\begin{array}{l}\text { Rata- } \\
\text { rata }\end{array}$} & \multirow[t]{2}{*}{ Kriteria } \\
\hline & & 1 & 2 & 3 & 4 & 5 & & & \\
\hline 3 & $\begin{array}{l}\text { Saya merasa Uniqlo } \\
\text { berkontribusi terhadap } \\
\text { lingkungan dengan } \\
\text { menggunakan bahan } \\
\text { organik sehingga dapat } \\
\text { mengurangi limbah pada } \\
\text { saat produksi produk } \\
\text { Uniqlo }\end{array}$ & - & - & 14 & 61 & 25 & 411 & 4.11 & Setuju \\
\hline 4 & $\begin{array}{l}\text { Menurut saya harga } \\
\text { produk Uniqlo sesuai } \\
\text { dengan bahan yang } \\
\text { digunakan pada } \\
\text { produknya }\end{array}$ & - & - & 22 & 52 & 26 & 404 & 4.04 & Setuju \\
\hline & & Rata-1 & & & & & & 4.16 & Setuju \\
\hline
\end{tabular}

Sumber: data diolah, 2020

Berdasarkan Tabel 4. diketahui persepsi responden mengenai variabel green marketing yang memperoleh nilai rata-rata sebesar 4,16, yang artinya responden setuju terhadap penyataan green marketing. Dalam pernyataan variabel green marketing yang memperoleh nilai rata-rata tertinggi dan terendah adalah sebagai berikut: Variabel green marketing yang memiliki rata-rata terendah adalah pernyataan "Menurut saya harga produk Uniqlo sesuai dengan bahan yang digunakan pada produknya", diperoleh nilai rata-rata sebesar 4,04 yang masuk kriteria setuju, tetapi memiliki nilai rata-rata yang rendah dibandingkan dengan pernyataan yang lainnya ini berarti secara umum responden masih menganggap bahwa harga pada produk Uniqlo masih tergolong cukup mahal. Variabel green marketing yang memiliki rata-rata tertinggi adalah pernyataan "Saya melihat produk Uniqlo dipromosikan dengan memanfaatkan teknologi digital sehingga dapat meminimalisir kerusakan bagi lingkungan", diperoleh nilai rata-rata sebesar 4,41 yang masuk kriteria sangat setuju, ini berarti secara umum responden menganggap Uniqlo mampu memanfaatkan teknologi digital untuk melakukan promosi.

Berdasarkan Tabel 5. diketahui persepsi responden mengenai variabel brand image yang memperoleh nilai rata-rata sebesar 3,95, yang artinya responden setuju terhadap penyataan brand image. Dalam pernyataan variabel brand iamge yang memperoleh rata-rata tertinggi dan terendah adalah sebagai berikut: Variabel brand image yang memiliki rata-rata terendah adalah pernyataan "Menurut saya produk Uniqlo lebih ramah lingkungan dibandingkan produk pakaian merek lain”, diperoleh nilai rata-rata sebesar 3,77 yang masuk kriteria setuju, tetapi memiliki nilai rata-rata yang rendah dibandingkan dengan pernyataan yang lainnya ini berarti secara umum responden masih menganggap bahwa bahan yang digunakan produk Uniqlo masih kurang ramah lingkungan dibandingkan merek lain. Variabel brand image yang 
memiliki rata-rata tertinggi adalah pernyataan "Saya melihat Uniqlo mempunyai desain yang terupdate/terbaru", diperoleh nilai rata-rata sebesar 4,12 yang masuk kriteria setuju, ini berarti secara umum responden menganggap bahwa Uniqlo memiliki desain yang terupdate/terbaru pada produknya.

\section{Tabel 5.}

Deskripsi Jawaban Responden Terhadap Brand Image

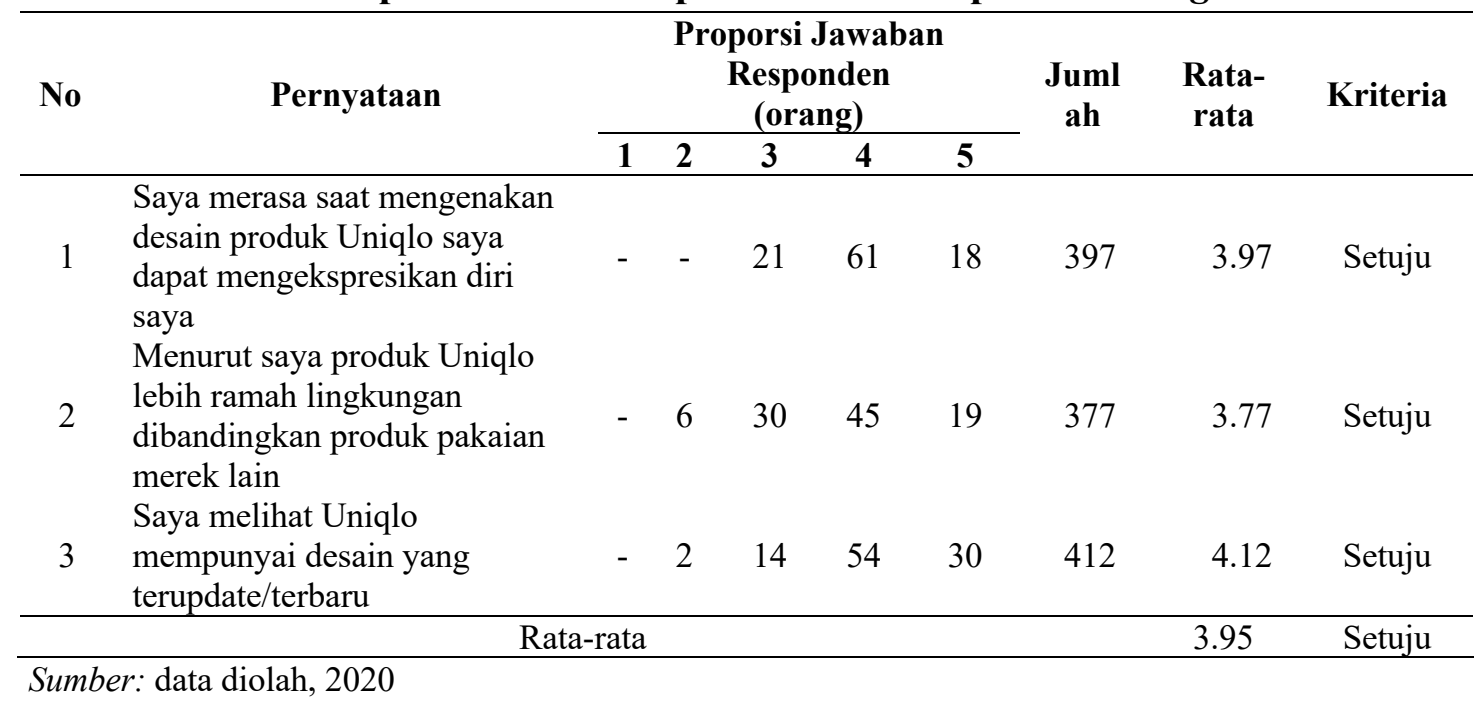

Tabel 6.

Deskripsi Jawaban Responden Terhadap Keputusan Pembelian

\begin{tabular}{|c|c|c|c|c|c|c|c|c|c|}
\hline \multirow[t]{2}{*}{ No } & \multirow[t]{2}{*}{ Pernyataan } & \multicolumn{5}{|c|}{$\begin{array}{c}\text { Proporsi Jawaban } \\
\text { Responden } \\
\text { (orang) }\end{array}$} & \multirow[t]{2}{*}{$\begin{array}{c}\text { Juml } \\
\text { ah }\end{array}$} & \multirow[t]{2}{*}{$\begin{array}{l}\text { Rata- } \\
\text { rata }\end{array}$} & \multirow[t]{2}{*}{ Kriteria } \\
\hline & & 1 & 2 & 3 & 4 & 5 & & & \\
\hline 1 & $\begin{array}{l}\text { Saya membeli produk } \\
\text { Uniqlo karena butuh } \\
\text { pakaian yang dapat } \\
\text { mengekspresikan } \\
\text { kepribadian saya dengan } \\
\text { tetap menjaga lingkungan }\end{array}$ & - & 3 & 20 & 60 & 17 & 391 & 3.91 & Setuju \\
\hline 2 & $\begin{array}{l}\text { Saya memutuskan } \\
\text { membeli produk Uniqlo } \\
\text { karena menggunakan } \\
\text { bahan-bahan ramah } \\
\text { lingkungan }\end{array}$ & - & 1 & 18 & 61 & 20 & 400 & 4.00 & Setuju \\
\hline
\end{tabular}


E-Jurnal Manajemen, Vol. 10, No. 6, 2021 : 539-559

Lanjutan Tabel 6.

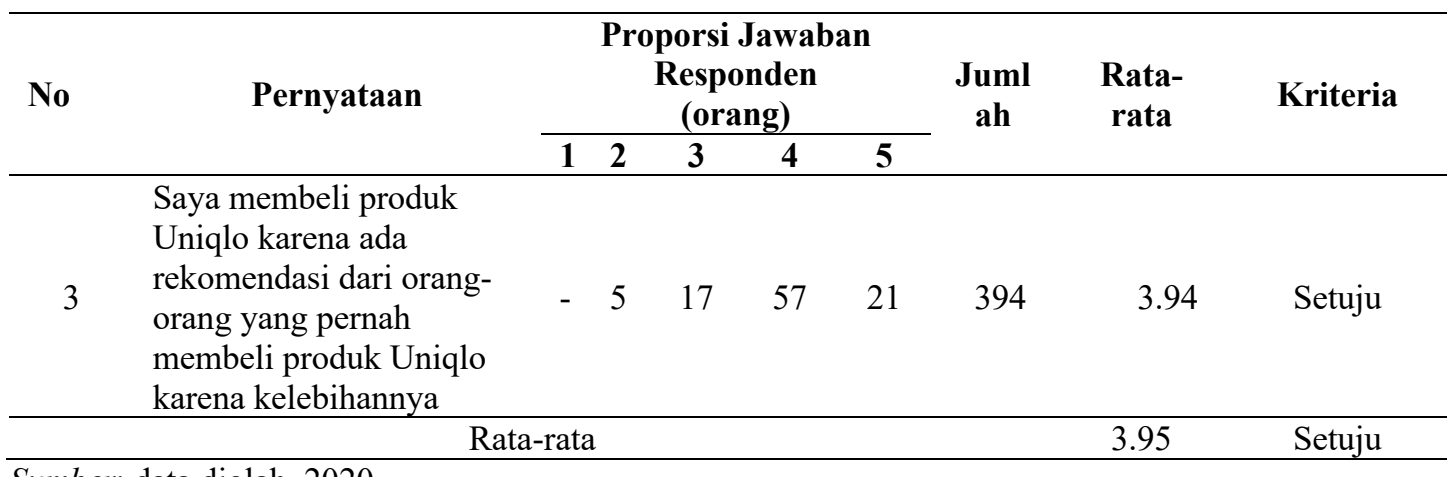

Sumber: data diolah, 2020

Berdasarkan Tabel 6. diketahui persepsi responden mengenai variabel keputusan pembelian yang memperoleh nilai rata-rata sebesar 3,95, yang artinya responden setuju terhadap penyataan keputusan pembelian. Dalam pernyataan variabel keputusan pembelian yang memperoleh nilai rata-rata tertinggi dan terendah adalah sebagai berikut: Variabel keputusan pembelian yang memiliki rata-rata terendah adalah pernyataan "Saya membeli produk Uniqlo karena butuh pakaian yang dapat mengekspresikan kepribadian saya dengan tetap menjaga lingkungan", diperoleh nilai rata-rata sebesar 3,91 yang masuk kriteria setuju, tetapi memiliki nilai rata-rata yang rendah dibandingkan dengan pernyataan yang lainnya ini berarti secara umum responden masih menganggap bahwa produk Uniqlo belum bisa mengekspresikan kepribadian bagi penggunanya. Variabel keputusan pembelian yang memiliki rata-rata tertinggi adalah pernyataan "Saya memutuskan membeli produk Uniqlo karena menggunakan bahan-bahan ramah lingkungan", diperoleh nilai rata-rata sebesar 4,00 yang masuk kriteria setuju, ini berarti secara umum responden merasa bahwa produk Uniqlo menggunakan bahan ramah lingkungan, sehingga konsumen tertarik untuk membeli produk Uniqlo

Uji asumsi klasik dilakukan dengan tujuan untuk memastikan hasil yang diperoleh memenuhi asumsi dasar di dalam analisis regresi. Hasil uji asumsi klasik yang dilakukan dalam penelitian ini adalah uji normalitas, uji multikolinieritas, dan uji heteroskedastisitas.

Tabel 7.

Uji Normalitas Data

\begin{tabular}{llr}
\hline & & $\begin{array}{c}\text { Unstandardized } \\
\text { Residual }\end{array}$ \\
\hline $\mathrm{N}$ & & 100 \\
Normal Parameters & Mean & .0000000 \\
& Std. Deviation & 0,43886155 \\
Most Extreme Differences & Absolute & 0,154 \\
\hline Bersambung... & &
\end{tabular}


Lanjutan Tabel 7.

\begin{tabular}{llr}
\hline & & \multicolumn{1}{c}{$\begin{array}{c}\text { Unstandardized } \\
\text { Residual }\end{array}$} \\
\hline & Positive & 0,086 \\
Kolmogorov-Smirnov $Z$ & Negative & $-0,154$ \\
Asymp. Sig. (2-tailed) & & 0,154 \\
Sumber. Sta & & 0,200 \\
\hline
\end{tabular}

Sumber: data diolah, 2020

Tabel 7. ditunjukkan bahwa nilai signifikansi Asymp. Sig. (2-tailed) sebesar $0,200(0,200>0,05)$ maka data berdistribusi normal.

\section{Tabel 8.}

Uji Multikolinieritas

\section{Collinearity Statistics}

\begin{tabular}{lccl}
\multirow{2}{*}{ Model } & \multicolumn{2}{c}{ Collinearity Statistics } & \multirow{2}{*}{ Keterangan } \\
\cline { 2 - 3 } & Tolerance & VIF & \\
\hline Green Marketing $(\mathrm{X})$ & 0.831 & 1.203 & Tidak ada multikolinieritas \\
\hline Brand Image $(\mathrm{M})$ & 0.831 & 1.203 & Tidak ada multikolinieritas \\
\hline
\end{tabular}

Sumber: data diolah, 2020

Dapat dilihat pada Tabel 8. bahwa nilai tolerance $0,831>0,10(10 \%)$ dan nilai VIF $1,203<10$ maka tidak terjadi gejala multikolinieritas dalam model.

Tabel 9.

Uji heteroskedastisitas

\begin{tabular}{lcc}
\hline \multicolumn{1}{c}{ Variabel } & Sig. & Keterangan \\
\hline Green Marketing $(\mathrm{X})$ & 0,053 & Bebas Heteroskedastisitas \\
Brand Image $(\mathrm{M})$ & 0,101 & Bebas Heteroskedastisitas \\
\hline
\end{tabular}

Sumber: data diolah, 2020

Berdasarkan Tabel 9, diketahui bahwa nilag Sig. dari variabel green marketing dan brand image lebih besar dari 0,05 yang berarti variabel tersebut tidak mengandung gejala heteroskedastisitas.

Tabel 10. menunjukan bahwa green marketing memiliki koefisien sebesar 0,411 berarti green marketing memiliki pengaruh positif terhadap brand image, ini diartikan apabila green marketing meningkat maka brand image akan meningkat. 
E-Jurnal Manajemen, Vol. 10, No. 6, 2021 : 539-559

Tabel 10.

Hasil Analisis Jalur Pada Struktur 1

\begin{tabular}{|c|c|c|c|c|c|}
\hline \multirow[t]{2}{*}{ Model } & \multicolumn{2}{|c|}{ Unstandardized Coefficients } & \multirow{2}{*}{$\begin{array}{c}\begin{array}{c}\text { Standardized } \\
\text { Coefficients }\end{array} \\
\text { Beta }\end{array}$} & \multirow[t]{2}{*}{$\mathbf{t}$} & \multirow[t]{2}{*}{ Sig. } \\
\hline & B & Std. Error & & & \\
\hline (Constant) & 2.066 & 0.426 & & 4.846 & 0.000 \\
\hline Green Marketing & 0.453 & 0.102 & 0.411 & 4.458 & 0.000 \\
\hline $\begin{array}{ll}\mathrm{R}^{2} & : 0,169\end{array}$ & & & & & \\
\hline
\end{tabular}

Tabel 11.

Hasil Analisis Jalur Pada Struktur 2

\begin{tabular}{|c|c|c|c|c|c|}
\hline \multirow[t]{2}{*}{ Model } & \multicolumn{2}{|c|}{ Unstandardized Coefficients } & \multirow{2}{*}{$\begin{array}{c}\text { Standardized } \\
\text { Coefficients }\end{array}$} & \multirow[t]{2}{*}{$\mathbf{t}$} & \multirow[t]{2}{*}{ Sig. } \\
\hline & B & Std. Error & & & \\
\hline (Constant) & 0.671 & 0.408 & & 1.644 & 0.103 \\
\hline Green Marketing & 0.325 & 0.096 & 0.288 & 3.398 & 0.001 \\
\hline Brand Image & 0.487 & 0.087 & 0.475 & 5.508 & 0.000 \\
\hline $\mathrm{R}^{2} \quad: 0,421$ & & & & & \\
\hline
\end{tabular}

Tabel 11. menunjukan green marketing memiliki koefisien sebesar 0,288 berarti green marketing memiliki pengaruh positif terhadap keputusan pembelian, ini diartikan apabila green marketing meningkat maka keputusan pembelian akan meningkat. Sedangkan brand image memiliki koefisien sebesar 0,475 berarti brand image memiliki pengaruh positif terhadap keputusan pembelian, ini diartikan apabila brand image meningkat maka keputusan pembelian akan meningkat.

Berdasarkan model substruktur 1 dan substruktur 2, maka dapat disusun model diagram jalur akhir. Sebelum menyusun model diagram jalur akhir, terlebih dahulu dihitung nilai standar eror sebagai berikut :

$$
\begin{aligned}
& \mathrm{e}_{\mathrm{i}}=\sqrt{1-\mathrm{R}_{\mathrm{i}}{ }^{2}} \ldots \ldots \ldots \ldots \ldots \ldots \ldots(1) \\
& \mathrm{e}_{1}=\sqrt{1-R_{1}{ }^{2}}=\sqrt{1-0,169}=0,911 \\
& \mathrm{e}_{\mathrm{i}}=\sqrt{1-\mathrm{R}_{\mathrm{i}}{ }^{2}} \\
& \mathrm{e}_{2}=\sqrt{1-{R_{2}}^{2}}=\sqrt{1-0,421}=0,761
\end{aligned}
$$


Pada perhitungan pengaruh error (e) maka didapatkan hasil untuk pengaruh error struktur $1\left(\mathrm{e}_{1}\right)$ sebesar 0,911 dan pengaruh error struktur $2\left(\mathrm{e}_{2}\right)$ sebesar 0,761. Hasil koefisien determinasi total adalah sebagai berikut :

$$
\begin{aligned}
\mathrm{R}^{2} \mathrm{~m} & =1-\left(\mathrm{e}_{1}\right)^{2}\left(\mathrm{e}_{2}\right)^{2} \ldots \ldots \ldots \\
& =1-(0,911)^{2}(0,761)^{2} \\
& =1-(0,830)(0,579) \\
& =1-0,481=0,520 .
\end{aligned}
$$

Berdasarkan hasil analisis perngaruh green marketing terhadap brand image memiliki nilai sig t. $0,000 \leq 0,05$ mengindikasikan bahwa $\mathrm{H}_{\mathrm{o}}$ ditolak dan $\mathrm{H}_{1}$ diterima yang berarti terdapat pengaruh yang siginifikan antara green marketing terhadap brand image. Dengan nilai koefisien beta sebesar 0,411 menunjukkan arah positif. Kesimpulannya adalah green marketing berpengaruh positif dan signifikan terhadap brand image.

Berdasarkan hasil analisis perngaruh green marketing terhadap keputusan pembelian memiliki nilai sig t. $0,001 \leq 0,05$ mengindikasikan bahwa $\mathrm{H}_{\mathrm{o}}$ ditolak dan $\mathrm{H}_{1}$ diterima yang berarti terdapat pengaruh yang siginifikan antara green marketing terhadap keputusan pembelian. Nilai koefisien beta sebesar 0,288 menunjukkan arah positif. Kesimpulannya adalah green marketing berpengaruh positif dan signifikan terhadap keputusan pembelian.

Berdasarkan hasil analisis perngaruh brand image terhadap keputusan pembelian, nilai sig t. $0,000 \leq 0,05$ mengindikasikan bahwa $\mathrm{H}_{0}$ ditolak dan $\mathrm{H}_{1}$ diterima yang berarti terdapat pengaruh yang siginifikan antara brand image terhadap keputusan pembelian. Nilai koefisien beta sebesar 0,475 menunjukkan arah positif. Kesimpulannya adalah brand image berpengaruh positif dan signifikan terhadap keputusan pembelian.

Tabel 12.

Pengaruh Langsung, Pengaruh Tidak Langsung Green Marketing (X), Terhadap Brand Image (M) dan Keputusan Pembelian (Y)

\begin{tabular}{cccc}
\hline $\begin{array}{c}\text { Pengaruh } \\
\text { Variabel }\end{array}$ & $\begin{array}{c}\text { Pengaruh } \\
\text { Langsung }\end{array}$ & $\begin{array}{c}\text { Pengaruh Tidak Langsung } \\
\text { Melalui } \\
\mathbf{M}\end{array}$ & Pengaruh Total \\
\hline $\mathrm{X} \rightarrow \mathrm{M}$ & 0,411 & - & 0,411 \\
\hline $\mathrm{X} \rightarrow \mathrm{Y}$ & 0,288 & 0,195 & 0,483 \\
\hline $\mathrm{M} \rightarrow \mathrm{Y}$ & 0,475 & - & 0,475 \\
\hline
\end{tabular}

Sumber: data diolah, 2020

Pada Tabel 12. mendapatkan hasil bahwa variabel green marketing memiliki pengaruh langsung terhadap brand image sebesar 0,411, dan brand image memiliki 
pengaruh langsung terhadap keputusan pembelian sebesar 0,475 , dan pengaruh total green marketing terhadap keputusan pembelian melalui brand image sebesar 0,483. Hal ini menunjukan bahwa brand image dapat memediasi green marketing terhadap keputusan pembelian secara parsial sebesar $48 \%$.

$Z=\frac{a b}{\sqrt{b^{2}} s_{a}^{2}+a^{2} s_{b}^{2}+s_{a}^{2} s_{b}^{2}}$

$Z=\frac{0,411 \times 0,475}{\sqrt{0,475^{2}} 0,102^{2}+0,411^{2} 0,087^{2}+0,102^{2} 0,087^{2}}$

$Z=3,210$

Berdasarkan hasil Uji Sobel menunjukkan bahwa hasil tabulasi $Z=3,210>1,96$ yang berarti variabel green marketing berpengaruh positif dan signifikan terhadap keputusan pembelian pada pembeli produk fashion merek Uniqlo di Kota Denpasar dengan mediasi brand image, sehingga brand image merupakan variabel mediasi pengaruh antara green marketing terhadap keputusan pembeli produk fashion merek Uniqlo di Kota Denpasar, Sehingga hipotesis keempat diterima.

Berdasarkan hasil penelitian responden setuju dengan penyataan dari intikatorindikator variabel green marketing, dengan kata lain semakin baik green marketing di dalam produk fashion merek Uniqlo maka semakin positif brand image pada produk fashion merek Uniqlo. Hasil analisis hipotesis pertama dapat diterima. Green marketing memegang peranan penting dalam meningkatkan brand image pada suatu produk. Hal ini sejalan dengan hasil penelitian yang dilakukan oleh Sari \& Setiawan (2017) green marketing berpengaruh positif dan signifikan terhadap brand image. Hal serupa juga didapat dari hasil penelitian yang dilakukan oleh Agustina et al. (2016), Chalimatuz et al. (2017), dan Wang et al. (2016) yang sama - sama menunjukkan bahwa startegi pemasar hijau memiliki pengaruh positif dan signifikan terhadap brand image, yang berarti bahwa dalam penerapan green marketing yang baik didalam suatu produk akan mampu meningkatkan brand image yang positif dimata konsumen.

Berdasarkan hasil penelitian responden setuju dengan penyataan dari intikatorindikator variabel green marketing, dengan kata lain semakin baik green marketing di dalam produk fashion merek Uniqlo maka semakin meningkat keputusan pembelian pada produk fashion merek Uniqlo. Hasil analisis hipotesis kedua dapat diterima. Pada penelitian yang dilakukan Dewi \& Rahyuda (2018) menyatakan bahwa green marketing memiliki peran penting dalam meningkatkan keputusan pembelian konsumen terhadap produk ramah lingkungan sehingga mampu mengurangi dampak negatif dari produk-produk sintetis yang dapat merusak lingkungan. Jamira \& Yandi (2019) menyatakan bahwa green marketing mempengaruhi keputusan pembelian dalam membeli atau memilih suatu produk. Hal yang sama ada penelitian yang 
dilakukan oleh Priyono (2017) bahwa green marketing dipandang mampu untuk meningkatkan pengambilan keputusan pembelian.

Berdasarkan hasil penelitian responden setuju dengan penyataan dari intikatorindikator variabel brand image, dengan kata lain semakin positif brand image di dalam produk fashion merek Uniqlo maka akan mampu mendorong keputusan pembelian pada produk fashion merek Uniqlo. Hasil analisis hipotesis ketiga dapat diterima. Sejalan dengan hasil penelitian dari Cahyani \& Sutrasmawati (2016) menyatakan bahwa semakin positif brand image pada perusahaan maka semakin meningkatnya penjualan, dan akan mempengaruhi keputusan pembelian konsumen. Hasil penelitian Adiwidjaja \& Tarigan (2017) brand image berpengaruh positif dan signifikan terhadap keputusan pembelian sepatu Converse baik melalui hubungan langsung maupun tidak langsung. Sejalan dengan penelitian Dewi \& Aksari (2017) brand image berpengaruh positif dan signifikan terhadap keputusan pembelian, hasil penelitian ini menunjukkan bahwa brand image perusahaan yang baik akan mendorong konsumen untuk meningkatkan keputusan pembelian terhadap suatu produk tersebut akan semakin tinggi, dan sebaliknya semakin lemah brand image suatu produk, maka potensi terjadinya suatu keputusan pembelian oleh konsumen akan mudah menurun.

Berdasarkan hasil penelitian responden setuju dengan penyataan dari intikatorindikator variabel green marketing, brand image dan keputusan pembelian, sehingga brand image merupakan variabel mediasi pengaruh antara green marketing terhadap keputusan pembelian pada produk fashion merek Uniqlo di Kota Denpasar. Hasil analisis hipotesis keempat dapat diterima. Green marketing merupakan salah satu solusi dan terobosan yang efektif dalam mengurangi pemanasan global. Perusahaan yang mampu membangun green marketing yang kuat, maka dengan mudah akan membangun citra positif pada perusahaan di benak konsumen. Brand image merupakan suatu pandangan konsumen terhadap produk atau jasa berdasarkan pengalaman, pengetahuan dan terhadap merek tersebut. Keputusan pembelian terjadi karena citra produk, citra perusahaan, dan citra pemakai yang baik. Brand image yang kuat memungkinkan konsumen untuk mengidentifikasi kebutuhan yang memuaskan dan cenderung memilih produk tersebut untuk melakukan suatu keputusan pembelian. Penelitian yang dilakukan oleh Chalimatuz et al. (2017) yang menyatakan bahwa green marketing dapat berperan dalam mendorong persepsi positif dari konsumen terhadap brand image yang mengacu pada lingkungan. Penelitian yang dilakukan oleh Cahyani \& Sutrasmawati (2016) memperoleh hasil bahwa brand image mempunyai pengaruh yang signifikan terhadap keputusan pembelian. Penelitian yang dilakukan oleh Dewi \& Aksari (2017) Brand image mampu memediasi pengaruh green marketing terhadap keputusan pembelian, hal ini menunjukan bahwa jika brand image yang dimiliki oleh produk atau jasa semakain baik maka dapat berpengaruh terhadap green marketing dalam memutuskan pembelian terhadap suatu produk. 


\section{SIMPULAN}

Berdasarkan hasil penelitian yang diperoleh, dapat diambil beberapa simpulan sebagai berikut. Green marketing berpengaruh positif dan signifikan terhadap brand image pada produk fashion merek Uniqlo di Kota Denpasar, hasil analisis hipotesis 1 dapat diterima. Green marketing berpengaruh positif dan signifikan terhadap keputusan pembelian pada produk fashion merek Uniqlo di Kota Denpasar, hasil analisis hipotesis 2 dapat diterima. Brand image berpengaruh positif dan signifikan terhadap keputusan pembelian pada produk fashion merek Uniqlo di Kota Denpasar, hasil analisis hipotesis 3 dapat diterima. Brand image merupakan variabel mediasi pengaruh antara green marketing terhadap keputusan pembelian pada produk fashion merek Uniqlo di Kota Denpasar, hasil analisis hipotesis 4 dapat diterima.

Berdasarkan hasil yang diperoleh dari segi green marketing perusahaan Unqilo harus lebih gencar dalam memberikan informasi, bisa melalui media sosial atau search engine marketing untuk memberi informasi tentang kualitas dari bahan-bahan yang digunakan dalam produk Uniqlo. Dari segi brand image Uniqlo harus tetap menjaga konsistensi dan meningkatkan program sustainability Uniqlo, dalam program ini Uniqlo harus lebih gencar dalam memberikan edukasi terkait manfaat dari penggunaan produk Uniqlo yang berbahan ramah lingkungan, Dari segi keputusan pembelian perusahaan harus terus mencari tahu perkembangan tren fashion, dan mencari informasi berkaitan dengan mode berpakaian pada masyarakat di Kota Denpasar dengan cara menyebarkan kusioner yang berkaitan dengan tren fashion Bagi penelitian selanjutnya diharapkan mampu mengganti lokasi penelitian yang tidak hanya terfokus pada suatu lokasi penelitian. Untuk penyebaran kuisioner, penelitian selanjutnya diharapkan bisa menyebarkan kuisioner secara langsung dilokasi penelitian agar mendapatkan data yang lebih baik. Selain itu juga untuk penelitian selanjutnya diharapkan menambah variabel- variabel yang dapat mempengaruhi keputusan pembelian, yaitu E-WOM (Electronic Word of Mouth), kepercayaan dan lain sebagainya yang dapat mempengaruhi keputusan pembelian.

\section{REFERENSI}

Adiwidjaja, A. J., \& Tarigan, Z. J. H. (2017). Pengaruh Brand Image Dan Brand Trust Terhadap Keputusan Pembelian Sepatu Converse. Agora - Online Graduate Humanities Journal, 5(3).

Agustina, R., DH, A., \& Wilopo, W. (2016). Pengaruh Pemasaran Hijau Terhadap Citra Merek Hijau Serta Dampaknya Pada Keputusan Pembelian (Survei pada Mahasiswa Jurusan Administrasi Bisnis Strata-1 Angkatan 2012/2013 dan 2013/2014 Fakultas Ilmu Administrasi Universitas Brawijaya yang Menggunakan Tis. Jurnal Administrasi Bisnis S1 Universitas Brawijaya, 33(1), 171-179.

Cahyani, K. I., \& Sutrasmawati, R. E. (2016). Pengaruh Brand Image Dan Brand Awareness Terhadap Minat Beli Sepeda Motor Honda Scoopy Dengan Minat Beli 
Sebagai Variabel Intervening (Studi Kasus Pada Konsumen Pt. Nusantara Sakti Di Kota Semarang). Jurnal Ilmu Administrasi Bisnis, 7(5), 113-122.

Chalimatuz, Nur, K., \& Kusuma, R. (2017). The Effect of Green Marketing Through Corporate Social Responsibility And Brand Image On The Purchase Intention Of The Body Shop Customers In Malang. Journal RJOAS, 5(65), 212-222. https://doi.org/DOI https://doi.org/10.18551/rjoas.2017-05.27

Dewi, K. A. A., \& Aksari, N. M. A. (2017). Peran brand Image dalam Memediasi Pengaruh Green Marketing terhadap Keputusan Pembelian Produk Oriflame. EJournal Manajemen Unud, 6(11), 6029-6060. https://ojs.unud.ac.id/index.php/Manajemen/article/view/33384/21236

Fure, F., Lapian, J., \& Taroreh, R. (2015). Pengaruh Brand Image, Kualitas Produk Dan Harga Terhadap Keputusan Pembelian Konsumen Di J.Co Manado. Jurnal Riset Ekonomi, Manajemen, Bisnis Dan Akuntansi, 3(1), 367-377.

http://www.balipost.com/news/2018/12/24/64588/Gubernur-Bali-KeluarkanPergub,Ini...html. (2018).

https://radarbali.jawapos.com/read/2019/12/26/171839/volume-sampah-didenpasar-diprediksi-naik-hingga-40-persen. (2019).

https://radarbali.jawapos.com/read/2020/02/11/178910/sehari-hasilkan-ribuan-tonsampah-citra-pariwisata-bali-bisa-terancam. (2020).

Jamira, A., \& Yandi, A. (2019). Peran Customer Value dalam Memediasi Green Marketing terhadap Keputusan Pembelian Mobil Low Cost Green Car (LCGC) di Kota Jambi. J-MAS (Jurnal Manajemen Dan Sains), 4(2), 392. https://doi.org/10.33087/jmas.v4i2.124

Jannah, W., \& Ady, S. U. (2017). Analisis Fundamental, Suku Bunga, Dan Overconfidence Terhadap Pengambilan Keputusan Investasi Pada Investor Di Surabaya. Ekspektra: Jurnal Bisnis Dan Manajemen, 1(2), 138-155. https://doi.org/10.1017/CBO9781107415324.004

Prasetya, E. G., Yulianto, E., \& Sunarti. (2018). Pengaruh Brand Image Terhadap Keputusan Pembelian (Survei Pada Mahasiswa Fakultas Ilmu Administrasi Bisnis Program Studi Administrasi Bisnis angkatan 2014 konsumen Air Mnineral Aqua). Jurnal Administrasi Bisnis, 62(2), 214-221.

Priyono, A. (2017). Pengaruh Green Marketing dan Identitas Merek pada Citra Merek terhadap Pengambilan Keputusan Pembelian Produk Ultra Milk di Area 
E-Jurnal Manajemen, Vol. 10, No. 6, 2021 : 539-559

Pemasaran Jakarta. Industrial Engineering Journal, 6(1), 4-9.

Putra, I. P. A. S. S., \& Suryani, A. (2015). Peran Green Trust Dalam Memediasi Green Perceived Value Terhadap Green Purchase Behavior Pada Produk Organik. EJurnal Manajemen Universitas Udayana, 4(10), 3015-3036.

Sari, I. A. W., \& Setiawan, P. Y. (2017). Pengaruh Green Marketing Dan Packaging Terhadap Brand Image Dan Loyalitas Pelanggan Pada Konsumen Starbucks Coffee. E-Jurnal Manajemen Universitas Udayana, 6(7), 3820-3849.

Setyaningrum, A., \& Madiawati, P. N. (2019). Green Marketing Terhadap Brand Image Produk Lampu LED Philips Di Kota Bandung. 1(2), 164-182. https://doi.org/10.1017/CBO9781107415324.004

Stevanie, C. (2015). Pengaruh Green Marketing Terhadap Nilai Yang Dipersepsikan Dalam Keputusan Pembelian Pada Ades (Studi Kasus Pada Mahasiswa/I Fakultas Komunikasi Dan Bisnis Telkom University). Jurna E-Proceeding Of Management, 2(1), 612-620. http://ejournal.bsi.ac.id/ejurnal/index.php/ecodemica/article/view/49/13

Wang, Y.-H., Ssu-Ting, C., \& Nai-Ning, C. (2016). An Empirical Study of the Effect of Green Marketing on Purchase Intention - Evidence from Green Restaurant. International Journal of Business and Social Science, 6(4), 1-14. www.ijbssnet.com

Widodo, S. (2020). Pengaruh Green Product Dan Green Marketing Terhadap Keputusan Pembelian Produk Elektronik Merk Sharp Di Electronic City Cipinang Indah Mall Jakarta Timur. Jurnal Ilmiah M-Progress, 10(1), 23-34.

Wulandari, R. D., \& Iskandar, D. A. (2018). Pengaruh Citra Merek Dan Kualitas Produk Terhadap Keputusan Pembelian Pada Produk Kosmetik. Jurnal Riset Manajemen Dan Bisnis (JRMB) Fakultas Ekonomi UNIAT, 3(1), 11-18. https://doi.org/10.36226/jrmb.v3i1.81

Adiwidjaja, A. J., \& Tarigan, Z. J. H. (2017). Pengaruh Brand Image Dan Brand Trust Terhadap Keputusan Pembelian Sepatu Converse. Agora - Online Graduate Humanities Journal, 5(3).

Agustina, R., DH, A., \& Wilopo, W. (2016). Pengaruh Pemasaran Hijau Terhadap Citra Merek Hijau Serta Dampaknya Pada Keputusan Pembelian (Survei pada Mahasiswa Jurusan Administrasi Bisnis Strata-1 Angkatan 2012/2013 dan 2013/2014 Fakultas Ilmu Administrasi Universitas Brawijaya yang Menggunakan Tis. Jurnal Administrasi Bisnis S1 Universitas Brawijaya, 33(1), 171-179. 
Cahyani, K. I., \& Sutrasmawati, R. E. (2016). Pengaruh Brand Image Dan Brand Awareness Terhadap Minat Beli Sepeda Motor Honda Scoopy Dengan Minat Beli Sebagai Variabel Intervening (Studi Kasus Pada Konsumen Pt. Nusantara Sakti Di Kota Semarang). Jurnal Ilmu Administrasi Bisnis, 7(5), 113-122.

Chalimatuz, Nur, K., \& Kusuma, R. (2017). The Effect of Green Marketing Through Corporate Social Responsibility And Brand Image On The Purchase Intention Of The Body Shop Customers In Malang. Journal RJOAS, 5(65), 212-222. https://doi.org/DOI https://doi.org/10.18551/rjoas.2017-05.27

Dewi, K. A. A., \& Aksari, N. M. A. (2017). Peran brand Image dalam Memediasi Pengaruh Green Marketing terhadap Keputusan Pembelian Produk Oriflame. EJournal Manajemen Unud, 6(11), 6029-6060. https://ojs.unud.ac.id/index.php/Manajemen/article/view/33384/21236

Fure, F., Lapian, J., \& Taroreh, R. (2015). Pengaruh Brand Image, Kualitas Produk Dan Harga Terhadap Keputusan Pembelian Konsumen Di J.Co Manado. Jurnal Riset Ekonomi, Manajemen, Bisnis Dan Akuntansi, 3(1), 367-377.

http://www.balipost.com/news/2018/12/24/64588/Gubernur-Bali-KeluarkanPergub,Ini...html. (2018).

https://radarbali.jawapos.com/read/2019/12/26/171839/volume-sampah-didenpasar-diprediksi-naik-hingga-40-persen. (2019).

https://radarbali.jawapos.com/read/2020/02/11/178910/sehari-hasilkan-ribuan-tonsampah-citra-pariwisata-bali-bisa-terancam. (2020).

Jamira, A., \& Yandi, A. (2019). Peran Customer Value dalam Memediasi Green Marketing terhadap Keputusan Pembelian Mobil Low Cost Green Car (LCGC) di Kota Jambi. J-MAS (Jurnal Manajemen Dan Sains), 4(2), 392. https://doi.org/10.33087/jmas.v4i2.124

Jannah, W., \& Ady, S. U. (2017). Analisis Fundamental, Suku Bunga, Dan Overconfidence Terhadap Pengambilan Keputusan Investasi Pada Investor Di Surabaya. Ekspektra: Jurnal Bisnis Dan Manajemen, 1(2), 138-155. https://doi.org/10.1017/CBO9781107415324.004

Prasetya, E. G., Yulianto, E., \& Sunarti. (2018). Pengaruh Brand Image Terhadap Keputusan Pembelian (Survei Pada Mahasiswa Fakultas Ilmu Administrasi Bisnis Program Studi Administrasi Bisnis angkatan 2014 konsumen Air Mnineral Aqua). Jurnal Administrasi Bisnis, 62(2), 214-221. 
E-Jurnal Manajemen, Vol. 10, No. 6, 2021 : 539-559

Priyono, A. (2017). Pengaruh Green Marketing dan Identitas Merek pada Citra Merek terhadap Pengambilan Keputusan Pembelian Produk Ultra Milk di Area Pemasaran Jakarta. Industrial Engineering Journal, 6(1), 4-9.

Putra, I. P. A. S. S., \& Suryani, A. (2015). Peran Green Trust Dalam Memediasi Green Perceived Value Terhadap Green Purchase Behavior Pada Produk Organik. EJurnal Manajemen Universitas Udayana, 4(10), 3015-3036.

Sari, I. A. W., \& Setiawan, P. Y. (2017). Pengaruh Green Marketing Dan Packaging Terhadap Brand Image Dan Loyalitas Pelanggan Pada Konsumen Starbucks Coffee. E-Jurnal Manajemen Universitas Udayana, 6(7), 3820-3849.

Setyaningrum, A., \& Madiawati, P. N. (2019). Green Marketing Terhadap Brand Image Produk Lampu LED Philips Di Kota Bandung. 1(2), 164-182. https://doi.org/10.1017/CBO9781107415324.004

Stevanie, C. (2015). Pengaruh Green Marketing Terhadap Nilai Yang Dipersepsikan Dalam Keputusan Pembelian Pada Ades (Studi Kasus Pada Mahasiswa/I Fakultas Komunikasi Dan Bisnis Telkom University). Jurna E-Proceeding Of Management, 2(1),

$612-620$.

http://ejournal.bsi.ac.id/ejurnal/index.php/ecodemica/article/view/49/13

Wang, Y.-H., Ssu-Ting, C., \& Nai-Ning, C. (2016). An Empirical Study of the Effect of Green Marketing on Purchase Intention - Evidence from Green Restaurant. International Journal of Business and Social Science, 6(4), 1-14. www.ijbssnet.com

Widodo, S. (2020). Pengaruh Green Product Dan Green Marketing Terhadap Keputusan Pembelian Produk Elektronik Merk Sharp Di Electronic City Cipinang Indah Mall Jakarta Timur. Jurnal Ilmiah M-Progress, 10(1), 23-34.

Wulandari, R. D., \& Iskandar, D. A. (2018). Pengaruh Citra Merek Dan Kualitas Produk Terhadap Keputusan Pembelian Pada Produk Kosmetik. Jurnal Riset Manajemen Dan Bisnis (JRMB) Fakultas Ekonomi UNIAT, 3(1), 11-18. https://doi.org/10.36226/jrmb.v3i1.81 